\title{
Improving Students' Reading Comprehension \\ By Using Survey, Question, Read, Recite, And Review (SQ3R) \\ Method
}

\author{
Savitri Vidya Larasati, Ahmad Dahlan Rais, Dwi Elyono
}

\author{
English Education Department \\ Teacher Training and Education Faculty \\ Sebelas Maret University of Surakarta
}

Email: vidya_dea@ymail.com

\begin{abstract}
The aims of this research were (1) to find out whether SQ3R method improved the students' reading comprehension or not and (2) to describe the implementation of SQ3R method. With regards to the second aim, the research was especially aimed at describing (1) the class situation and (2) the strengths and weaknesses of SQ3R method during the teaching and learning process. The research was conducted in two cycles for two months at a senior high school in Surakarta. Each cycle had five steps: identifying the problem, planning, implementing, observing, and reflecting the action. The research findings show that SQ3R method could improve the students' reading comprehension and the classroom situation. The mean score increased from pre-test, which was 70.76 , became 77.33 in cycle I, and improved to be 85.33 in cycle II. The improvement of the classroom situation can be seen from the facts that: (1) SQ3R method could stimulate the students' prior knowledge; (2) the students were more focused on the task; (3) they enjoyed themselves and had fun joining the teaching-learning process; (4) the classroom situation was more conducive; (5) they were brave to ask when they did not understand the teachers' explanation; (6) they paid attention to the lesson; and (7) they were active in the class.
\end{abstract}

Keywords: SQ3R method, reading comprehension, classroom situation

\section{INTRODUCTION}

For the students in this globalization era, English is very important because the government includes this subject into the curriculum. In the process of teaching and learning English, there are four language skills to master: listening, speaking, writing, and reading. Brown (2001: 313) states reading is treated as one of two or more interrelated skills. It means that reading has a role as a subject for the students' reading competence that provides opportunities to develop other skills as well. If the students' reading skill is poor, they are very likely to fail in their study or at least they will have difficulty in making progress.
Reading skill is not merely about reading aloud activity. Comprehension is the main goal of reading. Kennedy (1981: 192) states that reading comprehension is a thinking process by which pupil selects facts, information or ideas from printed materials, determines the meaning the author intended to transmit, decides how they relate to previous knowledge he has acquired and judges their appropriateness and worth for meeting his own need and objectives.

The teacher attempts to help the students to be able to use strategies in comprehending the message or information from the texts. The teacher needs to lead the students to know the purpose of the text and how the sentences are connected to each 
other in order to comprehend the content of the text. Mostly most teachers, when they teach reading skill, they ask the students to read the text and answer the questions from the text, and then, they correct them. This teaching method makes the class boring. The teacher needs to make the students more active in comprehending the text.

On the other hand, if the students have good ability in reading, they will have a better chance to succeed in their study. In the most general terms, it can be said that reading involves the reader, the text, and the interaction between the reader and the text (Aebersold and Field, 1997: 5). It is supported by Snow (2002: 11) that reading comprehension is the process of simultaneously extracting and constructing meaning through interaction and involvement with written language. Further, she says that in comprehending the text there are three important elements: reader, text, and activity.

The observation conducted by the researcher in a senior high school in Surakarta found that there was a problem with the students' reading comprehension. The students' reading comprehension in a senior high school in Surakarta was still low because of some factors related to the understanding of the text and classroom situation. Some factors related to the comprehension were: (1) the students had trouble in finding the main idea of the text; (2) they had trouble in finding the explicit information; (3) they had trouble in finding the implicit information; (4) it was difficult for them in guessing the meaning of a new word; (5) it was difficult for them in identifying the reference.

The unfavorable situation was obvious in the teaching and learning process, which could be seen in the following facts. First, the students were sleepy, bored, and not enthusiastic to follow the lesson. It happened because they didn't have enough chance to practice or express their idea, so they could not interact with one another to understand the material. Besides, most of them did not pay attention to the lesson. They often looked at their watch and hoped the lesson would end as soon as possible. Second, the difficulty of the text made them frustrated. Sometimes, the topic was unfamiliar and the student had no prior knowledge about that topic. Consequently, the students had no interest and were less motivated to read. They did not enjoy the lesson. Third, they lacked an adequate amount of vocabulary. They seldom looked for the meanings of words in dictionaries or asked other friends and the teacher. Fourth, the teacher lacked teaching technique variations, so the students often talked with others when the teacher was explaining the lesson. The classroom became noisy.

Based on the situation, the researcher applied SQ3R method in XI MIA 2 class of a senior high school in Surakarta to solve the problem. SQ3R is a reading comprehension method introduced by Francis Pleasant Robinson in his book Effective Study (1961:14-35). SQ3R stands for Survey, Question, Read, Recite and Review. SQ3R is a method of reading textbooks that will most likely enhance the understanding and retention of reading materials. In line with Smith and Barret (1979: 236), SQ3R is an excellent strategy for building comprehension with expository texts. When these five steps are used together, students are able to improve their reading comprehension and boost content area achievement.

Huber (2004) in Baier (2011: 26) argues that SQ3R is simply a variety of strategies placed together in the hope of gaining a comprehensive effect. The procedures of SQ3R method are: (1) the 
students have to skim and think about the text that they are going to read; (2) select the first boldface topic in the chapter and restate it in the form of a question; (3) read the text immediately to find the answer; (4) restate the answer in the students' own words and then write the response; (5) review the information and recall the main points and the detailed information of the text.

SQ3R has many advantages for the students: SQ3R encourages them to get deeper understanding of what they read, and focused on the main point of a text or book. Robinson (1961) says that SQ3R method is an efficient method for students to read faster, pick out the important points of the text, and memorize it. With a 'survey' at the beginning, it arouses the curiosity of the students about the material that will be learnt, so it can enhance the students' motivation. Next are the 'question and read' activities. The students are given the opportunity to ask or make a list of questions and try to find answers to the questions by carrying out reading activities. Thus, it can encourage them to think critically and have an active and meaningful learning. 'Recite and review' are the postreading activity in SQ3R method. They help the students summarize and organize ideas, so they can remember them in a long period of time.

The aims of this research were (1) to find out whether SQ3R method improved the students' reading comprehension or not and (2) to describe the implementation of SQ3R method. With regards to the second aim, the research was especially aimed at describing (1) the class situation and (2) the strengths and weaknesses of SQ3R method during the teaching and learning process.

\section{RESEARCH METHODS}

The research was conducted in the class of XI MIA 2 of a senior high school in
Surakarta. There were 42 students in the class XI MIA 2 consisting of 20 girls and 22 boys. It was conducted for six months. The research consisted of the pre-research activities, the actions, and the post-action activities.

According to Burns (1999: 30) defines action research as the application of fact finding to practical problem solving in a social situation with a view to improve the quality of action within it, and involve the collaboration and cooperation of researchers, practitioners, and laymen.

The procedures of action research are the breaking down of the four Kemmis and McTaggart's steps into several substeps, namely identifying the problem, planning the action, implementing the action, observing the action, reflecting the action, and revising the plan. In the research, the researcher used some techniques to collect the data as follows: interview, observation, questionnaire, and test (pre-test, post-test 1 , and post-test 2).

In analyzing the data, the researcher used descriptive statistic method to analyze the quantitative data, which were the students' pre-test and post-test scores, while the qualitative data were analyzed by using constant comparative method. To analyze the qualitative data, the researcher carried out the steps suggested by Burns (1999: 157160) as follows: (a) assembling the data that had been collected over the period of the research: field notes, students' worksheets, questionnaire, and the photographs during the action; (b) coding the data, in which the researcher gave specific marks in the field notes to identify positive and negative responses by the students; (c) comparing the students' pre- test and post- test scores to find out if there was improvement in their reading comprehension; (d) building interpretations, in which the researcher related the research 
findings to some underlying theories; (e) reporting the outcomes, in which the researcher presented the data gained during the research in the form of a report.

\section{RESEARCH FINDINGS AND DISCUSSIONS}

The research was conducted in the class of grade eleven of a senior high school in Surakarta. It consisted of two cycles; both of cycle 1 and cycle 2 consisted four meeting.
In the planning section, the researcher designed the lesson plan based on the syllabus to solve the problem. In every meeting, the researcher also prepared the students' worksheet. In cycle 1, the researcher implemented SQ3R method in reading comprehension during three meetings and one meeting for the first posttest. After doing post-test 1 , the researcher found that the students' average score improved. It can be seen from table1 and 2.

Table 1. The Average scores of the Pre-Test and Post-Test 1

\begin{tabular}{cccc}
\hline No. & Explanation & Pre-test Score & Post-test 1 Score \\
\hline 1 & Highest score & 92 & 96 \\
2. & Lowest score & 32 & 48 \\
3. & Average score & 70.76 & 77.33 \\
\hline
\end{tabular}

Table 2. The Average Scores of the Students' Reading Skills

\begin{tabular}{clcc}
\multicolumn{4}{c}{ In the Pre-Test and Post-Test 1 } \\
\hline No. & \multicolumn{1}{c}{ Skills } & $\begin{array}{c}\text { Average score of } \\
\text { pre-test }\end{array}$ & $\begin{array}{c}\text { Average score of } \\
\text { post-test 1 }\end{array}$ \\
\hline 1. & Main idea & 58.10 & 80.48 \\
2. & Word meaning & 74.29 & 88.57 \\
3. & Explicit information & 82.86 & 82.86 \\
4. & Implicit information & 57.62 & 85.71 \\
5. & Reference & 80.95 & 64.76 \\
\hline
\end{tabular}

Based on table 2, it can be concluded that there was an improvement in the students' reading comprehension. Although, there was a decrease in reference from 80.95 to 64.76 .

After cycle 1, the students' reading comprehension and the classroom situation in terms of the teaching and learning process showed strengths: the first strength was the students' responsibility increased; the second strength was that most of the students shared their ideas effectively; the third strength was that the students paid attention to the teacher's explanation; the fourth strength was that the method gave the students a new impression so that it reduced their boredom and made the atmosphere of learning more relaxing; the fifth strength was that there was a good interaction between the researcher and the students - the researcher could create a good atmosphere that motivated the students to take a part in the teaching and learning process; the sixth strength was that the question step could trigger the students' curiosity about the topic which helped them understand the text; and the seventh strength was that the result of the post-test 1 was higher than the result of the pre-test.

The researcher found several weaknesses in cycle 1: first, some students just memorized sentences without understanding the content of the text; second, some students were still passive; third, some students were still shy to speak their ideas because they were afraid to make mistakes; fourth, some students were noisy in the corner of the class; and fifth, the researcher got problem in managing time.

Considering the problems that occurred in cycle 1 , the researcher decided 
to continue to cycle 2 . In this cycle the researcher revised the plan to solve the problems that occurred in cycle 1 . Before starting the learning activities in cycle 2 , the researcher first prepared the instrument consisting of materials and worksheets. At the end the cycle 2 , the post test was conducted to determine whether students' ability to comprehend a text had improved.

The researcher conducted three meetings to deliver the material and one meeting for the second post-test. The result of the second post-test showed the students' progress in reading comprehension. It can be seen in Tables 3 and 4.

Table 3. Post-Test Scores of the Students' Reading Skills in the Cycle 2

\begin{tabular}{clccc}
\hline No. & \multicolumn{1}{c}{ Skills } & Highest & Lowest & Average \\
\hline 1. & Main idea & 100 & 20 & 83.81 \\
2. & Word meaning & 100 & 20 & 78.10 \\
3. & Explicit information & 100 & 40 & 88.10 \\
4. & Implicit information & 100 & 60 & 94.76 \\
5. & Reference & 100 & 40 & 81.84 \\
\hline \multicolumn{5}{c}{ Total of average score } \\
\hline
\end{tabular}

Table 4. The Average Score of the Students' Reading Skills In the Pre-Test, Post-Test 1, and Post-Test 2

\begin{tabular}{clccc}
\hline No. & \multicolumn{1}{c}{ Skills } & $\begin{array}{c}\text { Average score of } \\
\text { pre-test }\end{array}$ & $\begin{array}{c}\text { Average score } \\
\text { of post-test 1 }\end{array}$ & $\begin{array}{c}\text { Average score } \\
\text { of post-test 2 }\end{array}$ \\
\hline 1. & Main idea & 58.10 & 80.48 & 83.81 \\
2. & Word meaning & 74.29 & 88.57 & 78.10 \\
3. & Explicit information & 82.86 & 82.86 & 88.10 \\
4. & Implicit information & 57.62 & 85.71 & 94.76 \\
5. & Reference & 80.95 & 64.76 & 81.84 \\
\hline
\end{tabular}

It was clear that the students were successful in understanding the main idea, finding the reference, understanding the explicit and implicit information, and understanding the word meaning. The total number of students was 42 and the mean score was obtained from the total of the score divided by 42 . The students' mean score improvement of reading comprehension was showed in the table below.

Table 5. The Mean Score of the Pre-Test and Post-Test

\begin{tabular}{cccc}
\hline No & Test & Mean Score & Improvement \\
\hline 1 & Pre-test & 70.76 & \\
2 & Post-test 1 & 77.33 & 6.57 \\
3 & Post-test 2 & 85.33 & 8.00 \\
\hline
\end{tabular}

Figure 1. The Figure of the Students' Mean Score Improvement

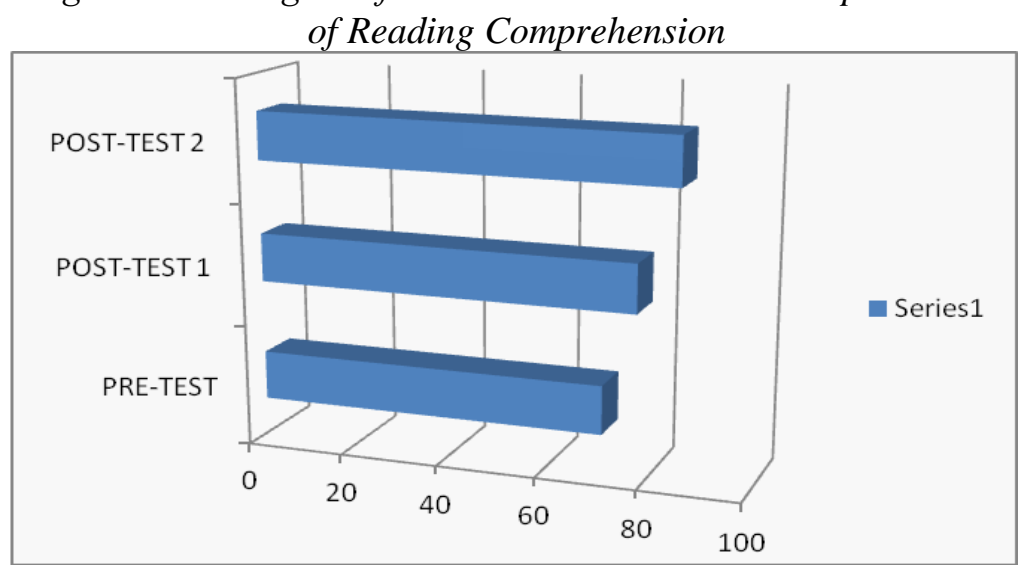


Figure 1 shows that there was an increase in the students' mean score for each cycle. Furthermore, the classroom climate also showed positive results. The students' learning progress in reading comprehension could be identified from the students' attention and participation during the teaching and learning process. The use of the SQ3R method gave a new impression to the students. The students could have better understanding about the reading text given to them. They also took part in the learning process. They were active in surveying and making questions. Almost all of the students were braver to express their ideas. Most of them tried to use English in expressing their ideas.

The situation of the class was inspiring. There was a good interaction between the students and the researcher. They also discussed and helped each other.
Questioning used by the researcher to know the students' feeling during the teaching and learning process, check their understanding of the materials, encourage their responses, and know what the students have known. It makes the students confidents to express their answers, retell story of the text, and show their ideas.

In the reading step, the students were active in reading, finding the meaning of difficult words and looking for the answers to the questions. In the step of reciting and reviewing, the students tried to retell the content of the story in their own words, made a final summary and suggested moral values related to the story. The improvement of class situation as can be seen in the following table.

Table 6. The improvement of Class Situation before Cycle 1, after Cycle 1, and after Cycle 2

\begin{tabular}{|c|c|c|}
\hline $\begin{array}{l}\text { - The students were not } \\
\text { interested to the } \\
\text { previous technique. } \\
\text { - The students paid little } \\
\text { attention toward the } \\
\text { teacher. } \\
\text { - Most of the students } \\
\text { were afraid to speak out } \\
\text { their ideas and answer } \\
\text { the researchers' } \\
\text { questions directly. }\end{array}$ & $\begin{array}{l}\text { - The students showed their } \\
\text { interest to SQ3R method. } \\
\text { - The SQ3R method could } \\
\text { help the students to read } \\
\text { effectively. } \\
\text { - Some students showed } \\
\text { their progress by speaking } \\
\text { out the ideas and } \\
\text { answering the questions } \\
\text { directly. }\end{array}$ & $\begin{array}{l}\text { Classroom situation } \\
\text { - The students were active. They } \\
\text { spoke bravely in asking } \\
\text { questions and showing their } \\
\text { ideas. } \\
\text { - All the students enjoyed and } \\
\text { were interested in the } \\
\text { classroom. } \\
\text { - The teaching and learning } \\
\text { activities run systematically due } \\
\text { to the implementation of SQ3R } \\
\text { method. } \\
\text { - All the steps in SQ3R method } \\
\text { were done in a good way. } \\
\text { - The students were more } \\
\text { focused on their own tasks. } \\
\text { - Students were brave to speak } \\
\text { their ideas and answer the } \\
\text { questions directly; almost of } \\
\text { them were not reluctant } \\
\text { anymore. }\end{array}$ \\
\hline
\end{tabular}

\section{CONCLUSIONS AND SUGGESTIONS}

The research was aimed to describe how SQ3R method improved the reading comprehension of the students of the eleventh grade of a senior high school in Surakarta and describe how the method could improve classroom situation. Considering the findings and the results of 
the discussion, some conclusions can be drawn as follows:

The SQ3R method could improve the students' reading comprehension. It can be seen from the increase in the students' mean score from 70.76 in the pre-test to

77.33 in the post-test of cycle 1 , and 85.33 in the post-test of cycle 2 .

During the implementation of the SQ3R method, the students were able to comprehend the whole text in terms of recognizing the main ideas, finding the implicit information, identifying the detailed information, finding the certain meaning of words and phrases, and identifying the references of the text.

The strengths of SQ3R found out during its implementation are: the first strength was that the class became more enjoyable and fun; the second strength was that the students were active and brave to speak aloud; the third strength was that the students were more focused on the task and classroom activities; the fourth strength was that the students had strong motivation to read the whole text; the fifth strength was that the surveying activity in the pre-task and the giving of some questions based on the students' schemata related to the topic could stimulate the students' prior knowledge; and the sixth strength was that SQ3R method helped the students to make notes of the information from the text - by asking them to study a set of vocabulary they did not know in the text, the researcher equipped the students with a method to relate their prior knowledge with the new information.

The weaknesses of SQ3R method found out in its implementation are: first, the researcher got difficulty to manage all students; second, it was difficult for the students who had low prior knowledge to participate actively in the teaching and learning process; third, the process took time; and fourth, the researcher needed more preparation.

Considering the results of the research, some suggestions to improve reading comprehension are provided. The students who were taught using SQ3R method should be active and creative in the teaching and learning process. They should develop their ability in comprehending the text. English teachers can use SQ3R method as an alternative method for teaching reading. They can combine SQ3R method with other media or techniques to develop the students' interest and motivation. Schools should encourage their English teachers to be more creative in using various media and providing meaningful activities for the students, so that they are able to optimally learn English in a fascinating classroom situation.

\section{BIBLIOGRAPHY}

Aebersold, Jo Ann and Field, Mary Lee. (1997). From reader to reading teacher. Cambridge: Cambridge University Press.

Baier, Kylie. (2011). The effects of sq3r on fifth grade students' comprehension levels. A Thesis Submitted to the Graduate College of Bowling Green State University in partial fulfillment of the requirements for the degree of Master of Education.

Burns, Anne. (1999). Collaborative action research for English language teacher. Cambridge: Cambridge University Press.

Brown, H. Douglas. (2001). Teaching by principal an interactive approach pedagogy. New York: Addison Wesley Longman Inc.

Kennedy, Eddie. (1981). Method in teaching develop mental reading second edition. USA: FE. Peacock Publisher, Inc. 
Robinson, Francis.P. (1961). Sq3r effective study. London: Harper \& Row Publisher.

Smith, Richard J. and Barrett, Thomas C. (1979). Teaching reading in the middle grades. Reading, MA:
Addison Wesley Publishing Company.

Snow, Catherine E. (2002). Reading for understanding: Toward a research and development program in reading comprehension. Santa Monica 